\title{
Genetic Risk Factors for Alzheimer's Disease in Racial/Ethnic Minority Populations in the U.S.: A Scoping Review
}

\begin{abstract}
Lindsey Rubin ${ }^{1}$, Lucy A. Ingram ${ }^{1 *}$, Nicholas V. Resciniti ${ }^{2}$, Brianna Ashford-Carroll', Katherine Henrietta Leith ${ }^{1}$, Aubrey Rose ${ }^{3}$, Stephanie Ureña ${ }^{1}$, Quentin McCollum ${ }^{4}$ and Daniela B. Friedman ${ }^{1}$

1 Department of Health Promotion, Education, and Behavior, University of South Carolina, Columbia, SC, United States, ${ }^{2}$ Department of Epidemiology and Biostatistics, University of South Carolina, Columbia, SC, United States, ${ }^{3}$ School of Medicine, University of South Carolina, Columbia, SC, United States, ${ }^{4}$ College of Social Work, University of South Carolina, Columbia, SC, United States
\end{abstract}

Objectives: As the United States (U.S.) population rapidly ages, the incidence of Alzheimer's Disease and Related Dementias (ADRDs) is rising, with racial/ethnic minorities affected at disproportionate rates. Much research has been undertaken to test, sequence, and analyze genetic risk factors for ADRDs in Caucasian populations, but
OPEN ACCESS

Tushar Trivedi,

Regional Medical Center,

United States

Reviewed by:

Xiangzhu Zhu,

Vanderbilt University, United States

Marcos Vasconcelos Pais,

University of São Paulo, Brazil

*Correspondence:

Lucy A. Ingram

lannang@sc.edu

Specialty section:

This article was submitted to Life-Course Epidemiology and Social Inequalities in Health

a section of the journal

Frontiers in Public Health

Received: 29 September 2021

Accepted: 23 November 2021

Published: 24 December 2021

Citation:

Rubin L, Ingram LA, Resciniti NV, Ashford-Carroll B, Leith KH, Rose A,

Ureña S, McCollum $Q$ and

Friedman DB (2021) Genetic Risk

Factors for Alzheimer's Disease in Racial/Ethnic Minority Populations in the U.S.: A Scoping Review.

Front. Public Health 9:784958. doi: 10.3389/fpubh.2021.784958
Edited by: comparatively little has been done with racial/ethnic minority populations. We conducted a scoping review to examine the nature and extent of the research that has been published about the genetic factors of ADRDs among racial/ethnic minorities in the U.S.

Design: Using an established scoping review methodological framework, we searched electronic databases for articles describing peer-reviewed empirical studies or Genome-Wide Association Studies that had been published 2005-2018 and focused on ADRD-related genes or genetic factors among underrepresented racial/ethnic minority population in the U.S.

Results: Sixty-six articles met the inclusion criteria for full text review. Well-established ADRD genetic risk factors for Caucasian populations including APOE, APP, PSEN1, and PSEN2 have not been studied to the same degree in minority U.S. populations. Compared to the amount of research that has been conducted with Caucasian populations in the U.S., racial/ethnic minority communities are underrepresented.

Conclusion: Given the projected growth of the aging population and incidence of ADRDs, particularly among racial/ethnic minorities, increased focus on this important segment of the population is warranted. Our review can aid researchers in developing fundamental research questions to determine the role that ADRD risk genes play in the heavier burden of ADRDs in racial/ethnic minority populations.

Keywords: genetic risk factors, Alzheimer's disease, race, ethnicity, minority, review

\section{INTRODUCTION}

As the United States (U.S.) population rapidly ages, the incidence of Alzheimer's Disease and related dementias (ADRD) is on the rise $(1,2)$. Alzheimer's Disease (AD) is the sixth leading cause of death in the U.S. and the fifth leading cause of death for those age 65 years and older $(1,2)$. In the U.S., 5.7 million people are living with $\mathrm{AD}$, which is projected to grow to 13.9 million adults ( $3.3 \%$ of the 
population) by 2060 (2). Although the primary risk factor for ADRD is age, race, and ethnicity are also associated with ADRD (2-4).

The U.S. population is becoming more racially and ethnically diverse, with Census projections showing that the country will be a "majority-minority" nation by 2050 . That is, racial/ethnic minorities will comprise more than $50 \%$ of the population by this date (5). African Americans are twice as likely as NonHispanic Whites to have AD, while Hispanics are 1.5 times as likely to have $\mathrm{AD}$ compared to their Non-Hispanic White counterparts (1). Also by 2050 in the U.S., it is estimated that the proportion of racial/ethnic minorities who suffer from $\mathrm{AD}$ will double in size compared to current figures (6). Regarding rates of diagnoses, in particular, African Americans are diagnosed later in the course of ADRD than White patients. Quinones et al. (7) suggest that this is likely due to cultural factors and normalization of ADRD symptoms as part of the usual aging process. There are also noted disparities in cognitive decline and impairment with racial/ethnic minorities suffering greater cognitive decline after ADRD diagnosis compared to other groups (8-10), potentially related to socio-economic resources, such as education quality, development of cognitive reserve, financial means, and early midlife stressors (7). Racial/ethnic health disparities in the U.S. proliferate, are multilayered, and are rooted in a variety of structural and historical inequalities that continue to disproportionately burden racial/ethnic minorities. These disparities underscore the need to examine the factors underlying ADRD in racial/ethnic minority U.S. populations.

As our population ages and the size of our minority populations increase in the U.S., understanding the burden of ADRD on our aging populations can aid in providing insight into the most appropriate and effective public health actions. For example, to provide the best care and community support for aging minority populations, it is valuable to understand any patterns of genetic risk factors to address comorbid disease management, environmental, and socio-economic factors that may affect ADRD prevention, diagnosis, and progression. Similarly, more precise knowledge of differences in prevalence of ADRD in minority populations is useful for policy planning when allocating resources, ensuring access to care, and improving quality of care (11).

Much research has been undertaken to test, sequence, and analyze genetic risk factors for ADRD in White populations, but comparatively little has been done with racial/ethnic minority populations (12). In fact, examining genetic factors in heath disparities research has sometimes led to intense controversy $(13,14)$, oftentimes for concern of the racialization of medicine, misuse of pharmacogenomics, and racial biology (15-17). In studies that have explored ADRD genetic risk factors in minorities, the study sizes have been relatively small, making the conclusions about genetic associations less powerful. Some data appears to show differences in the genetic etiologies between Caucasians and African Americans, especially relating to the APOE gene, which needs to be explored further $(11,18,19)$.
There are multiple types of $\mathrm{AD}$ classified by age at onset and method of inheritance. The two main categories from a genetic perspective are Early Onset Alzheimer's Disease (EOAD) and Late Onset Alzheimer's Disease (LOAD). According to the National Institute on Aging website, EOAD is also referred to as Familial Alzheimer's Disease and follows an autosomal dominant inheritance pattern, meaning that only one allele from either parent is required to cause disease. EOAD is caused by mutations in three genetic loci, APP, PSEN1, and PSEN2 (20-22). Late Onset Alzheimer's Disease, which is also referred to as Sporadic Alzheimer's Disease, is polygenic, meaning that multiple genes along with environmental factors contribute to the risk of $\mathrm{AD}$, age of onset, and severity of disease $(20,21)$. $A P O E$ is one of the most well-established genetic risk factors for LOAD and has implications for risk of other types of $A D$ $(20,21)$.

The APOE e4 allele is a strong risk factor for Sporadic or Late-Onset Familial AD, with the degree of risk increased with two copies of the allele (homozygous e4/e4), but possession of an e4 allele is not in itself necessary to produce $\mathrm{AD}$ or sufficient alone to cause the disease (23). Homozygosity in genetics refers to an individual with two copies of the same allele at a particular genetic loci or gene, while heterozygosity refers to the presence of two different alleles at a loci or gene (24). The effects of homozygosity and heterozygosity for the e4 allele has been studied extensively in European American populations, with homozygotes having a 12 times increased risk of LOAD, and heterozygotes having a 2-3 times increased risk of $\operatorname{LOAD}(18,19)$. In African American populations and Hispanic populations, e4 heterozygosity or homozygosity does not correlate with increased risk of $\mathrm{AD}$, indicating that other genetic and environmental factors are responsible for the increased incidence and prevalence of $\mathrm{AD}$ in these populations (25-27).

Examining genetic risk factors for ADRDs in minority populations can deepen our understanding of the interaction between biological or genetic factors and socio-ecological determinants of health. It also has the potential to aid in preventive care and early diagnosis for these populations with greater incidence of ADRDs (28). To better understand the risk profile of racial/ethnic minorities who are impacted by ADRD, research should be conducted to comprehend the disease mechanism in these populations, including influential genetic risk factors. If advances in genomic medicine continue to be valid, reliable, and promising, racial/ethnic minorities should be afforded the opportunities to participate in research at similar rates as their White counterparts (13). Other systematic reviews have been conducted in this general subject area. These reviews have had a more segmented focus, with some examining one specific gene and others focusing on a specific population (29, 30). Additional scoping or systematic reviews were focused on a single type of ADRD, such as Lewy Body Dementia or LOAD $(31,32)$. To explore this gap in the literature, we conducted a scoping review to examine the nature and extent of research that has been published about the genetic factors of ADRDs among racial/ethnic minorities in the U.S. 


\section{METHODS}

\section{Search Strategy and Selection Criteria}

Our study protocol was developed using the established and peer-reviewed scoping review methodological framework and updated based on prior ADRD-focused scoping reviews (3338). Scoping reviews are a useful format used to explore fields of study not already well-explored or defined. A scoping review is a "preliminary assessment of the potential size and scope of available research literature. It aims to identify the nature and extent of research evidence" [(39), p. 31]. Scoping reviews can be utilized for a variety of research purposes including discovering the scope of existing research in a field of study, in order to identify gaps in the literature for future study. Scoping reviews can also be used to explore the need for a systematic review and the potential value of a systematic review $(34,38)$.

The databases used to conduct the search were PubMed, CINAHL, and Science Direct. We chose to limit the search to those articles published from 2005 to 2019, as 2005 is when next generation DNA sequencing was available, allowing for more extensive genetic studies with larger sample sizes (40). We conducted a search within the databases using a combination of three concepts: (1) ADRD Genes, (2) Populations and Minority Groups, and (3) ADRDs. The search used a combination of terms from the three concepts to find articles relevant to our research questions. Specific ADRD candidate gene terms were chosen by recent data from Genome Wide Association Studies (GWAS) $(41,42)$. Some included terms were: APOE, beta Amyloid Protein Precursor, CD2AP, Genetic Predisposition to Disease, PSEN1, PSEN2, STM2, APP, TREM2, African American, Alaska Native, Arabs, Asian American, Ethnic Groups, Hispanic American, Native American, Jews, Minority Groups, Alzheimer's Disease, Dementia, Lewy Bodies, Lewy Body Disease. Inclusion criteria for the review were (1) articles published after January 1, 2005, (3) available in English, (3) peer reviewed empirical studies or Genome-Wide Association Studies (GWAS) (4) that focus on or include an underrepresented minority population in the U.S., (5) that focus on ADRDs, and (6) that focus on ADRD-related genes or genetic factors.

\section{Data Extraction and Synthesis}

The study selection process included three interrelated steps: Title/abstract reviews, full-article reviews, and reviewers' examination of reference lists from full articles to identify articles for possible inclusion (43). First, five out of nine of our team members were randomly assigned to review the 1,134 article titles and abstracts in Covidence systematic review online software, with each abstract randomly assigned to two reviewers. Two team members were designated as arbitrators for review discrepancies. When a discrepancy occurred between reviewers (e.g., one "Yes, include in the review" and one "No, do not include in the review"), the designated team members arbitrated the discrepancy. When both randomly assigned reviewers marked an abstract as "Yes" for inclusion, Covidence automatically moved it into the full article review list. Once all titles and abstracts were reviewed twice and all discrepancies arbitrated, the research team then performed a complete review of the resulting 115 articles.
Seven team members were randomly assigned a set of articles for full review and the same inclusion and exclusion criteria were used. A data abstraction tool was developed to facilitate review of the full articles and to abstract relevant data. The tool included 21 questions to aid in summarizing the key characteristics of each article. Discrepancies on final article selection and data extraction were then arbitrated by two team members with consultation with the rest of the research team. Once all full articles had been determined, the abstracted data were converted to a Microsoft Excel file for management.

\section{RESULTS}

\section{Studies Identified}

From the searches in all three databases there were a total of 1,891 articles and 14 additional articles identified from reference lists, for a total of 1,905 . We removed 771 duplicates, for a total 1,134 articles for the abstract review stage. During the title abstract review we excluded 1,019 articles due to the following reasons: published outside of the date range, article not available in English, dissertation, metanalysis, systematic review, scoping review, not focused on ADRD, not focused on minority U.S. population, not focused on ADRD genetic factors. After title abstract review, 115 articles remained for full text review. An additional 49 articles were excluded during the full-text review stage if the criteria were not met through examination of the full article. The full text review resulted in 66 included articles (see Figure 1).

\section{Populations and Genes Examined}

Tables 1, 2 present the general characteristics of the studies included in the full-text review. Table 3 presents a detailed listing of the characteristics of the articles that were included in the fulltext review. Among the resulting 66 studies, most of the studies ( $n$ $=41,62 \%$ ) were focused on African Americans as the population of interest followed by those focusing on the Hispanic population $(n=28,42 \%)$. Asian American populations were examined in seven out of the 66 studies (11\%), and Native American/Alaska Natives populations were included in only one study $(1.5 \%)$ (Table 1).

There were many different study designs represented in our results. The most common study design was a case control study design, with 18 included articles using this design. The next most frequently found study design was crosssectional with 15 included studies in this category. There were nine GWAS which is expected because candidate risk genes for ADRD in minority populations have not been fully established. There were five longitudinal studies in the results and two case studies. Lastly, there were five studies that could not be classified into one of these categories (Table 1).

Many different types of ADRDs were represented in our search results. The most frequently examined type of $\mathrm{AD}$ in our results was $\mathrm{LOAD}(n=26,40 \%)$, followed by $\mathrm{AD}(n=12,18 \%)$ and $\operatorname{EOAD}(n=7,11 \%)$. Vascular Dementia was the focus of four articles out of the total 66 results $(n=4,6 \%)$. Both Mild Cognitive Impairment (MCI) and Cognitive Decline were examined in two 


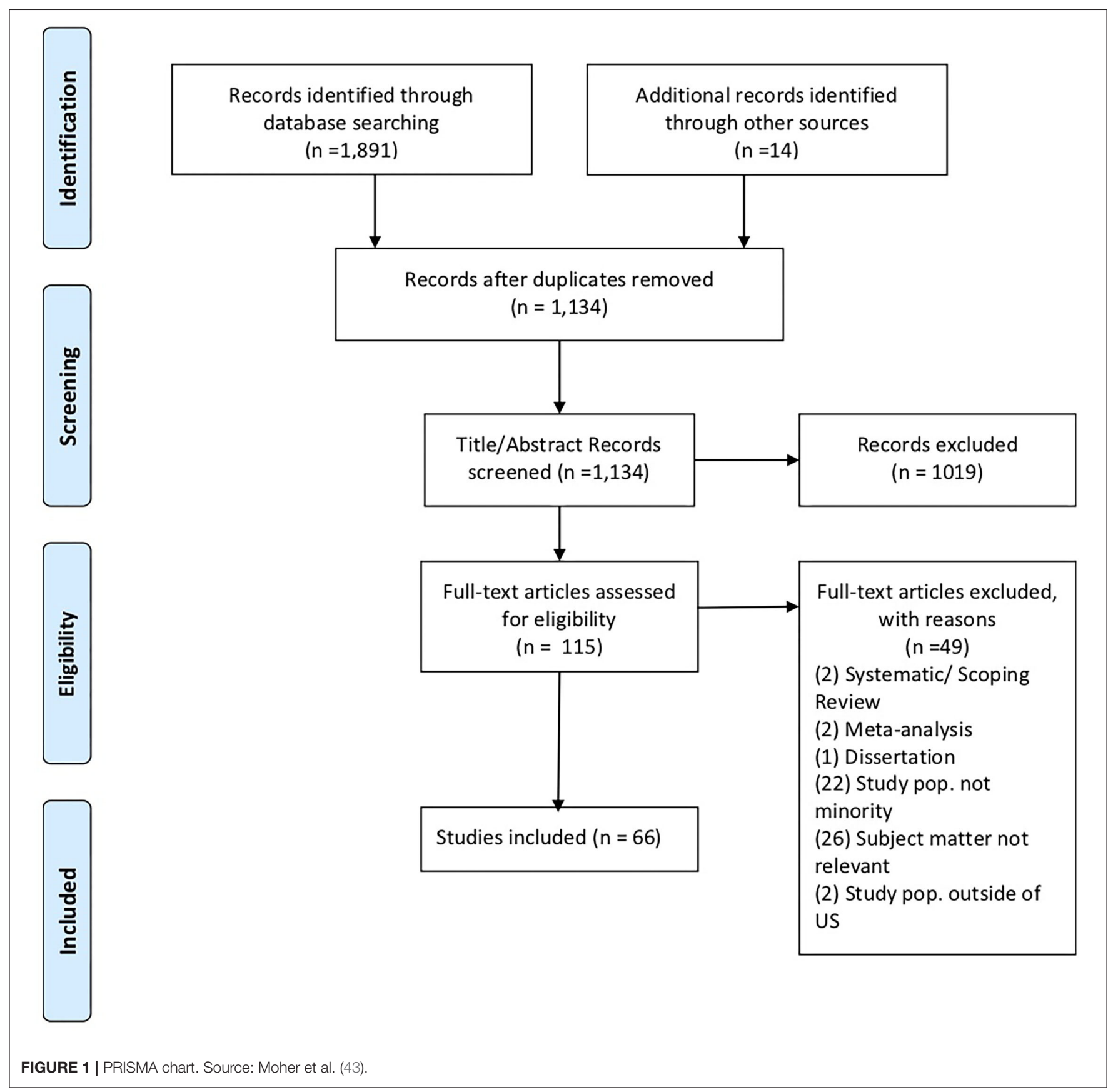

articles each $(n=2,3 \%)$. Lewy Body Dementia was the subject of one article $(n=1,1.5 \%)$. Lastly, there were 20 articles that did not specify a particular ADRD designation $(n=20,30 \%)$ (Table 2).

In terms of specific ADRD risk genes, $A P O E$ was examined in most studies, with 44 out of 66 included studies examining this genetic risk factor. Other potential ADRD risk genes that were examined by multiple studies included $A B C A 7, C L U, C R 1$, PICALM, APP, PSEN1, SORL1 and AKAP9, APP, and PSEN1 are well-established genetic risk factors for EOAD, but in total, they were examined in only eight out of 66 included studies (Table 2).

\section{DISCUSSION}

Our findings provide an overview of the published literature examining the association between genetic factors and ADRD risk among racial/ethnic minorities in the U.S. These findings help to illuminate knowledge gaps and suggest whether further study should be undertaken to assess more comprehensively the role that $\mathrm{ADRD}$ genes play in $\mathrm{AD}$ rates and disease outcomes for minority populations.

Regarding the extent of the genes examined in the studies that we found, $A P O E$ was examined in most studies, with 44 
TABLE 1 | Characteristics of studies included in the full-text review $(N=66)$.

\begin{tabular}{|c|c|c|}
\hline Characteristic & Number & Percentage (\%) \\
\hline \multicolumn{3}{|l|}{ Publication year } \\
\hline 2005-2006 & 7 & 10.6 \\
\hline 2007-2008 & 6 & 9.1 \\
\hline 2009-2010 & 5 & 7.6 \\
\hline 2011-2012 & 9 & 13.6 \\
\hline 2013-2014 & 15 & 22.7 \\
\hline 2015-2016 & 9 & 13.6 \\
\hline 2017-2018 & 15 & 22.7 \\
\hline \multicolumn{3}{|l|}{ Race/Ethnicity ${ }^{a}$} \\
\hline African American & 41 & 62.1 \\
\hline Hispanic American & 28 & 42.4 \\
\hline Asian American & 7 & 10.6 \\
\hline Native American/Alaska Native & 1 & 1.5 \\
\hline \multicolumn{3}{|l|}{ Sample size } \\
\hline $0-100$ & 3 & 4.5 \\
\hline $101-500$ & 11 & 16.7 \\
\hline $501-1,000$ & 10 & 15.2 \\
\hline $1,001-1,500$ & 11 & 16.7 \\
\hline $1,501-2,000$ & 7 & 10.6 \\
\hline $2,001-2,500$ & 4 & 6.1 \\
\hline $2,501-3,000$ & 2 & 3.0 \\
\hline $3,001-3,500$ & 2 & 3.0 \\
\hline 3,501-4,000 & 0 & 0.0 \\
\hline $4,001-4,500$ & 1 & 1.5 \\
\hline 4,501 or more & 15 & 22.7 \\
\hline \multicolumn{3}{|l|}{ Type of study } \\
\hline Case-control & 18 & 27.3 \\
\hline Cross-sectional & 15 & 22.7 \\
\hline Cohort & 12 & 18.2 \\
\hline Genome Wide Association Study (GWAS) & 9 & 13.6 \\
\hline Longitudinal & 5 & 7.6 \\
\hline Other & 5 & 7.6 \\
\hline Case report/case study & 2 & 3.0 \\
\hline
\end{tabular}

a Some articles included multiple races/ethnicities in the study sample.

out of 66 included studies examining this genetic risk factor. This corresponds with extant ADRD genetic risk factor research findings in general, as APOE is the most well-established genetic risk factor for Sporadic or LOAD (23). We found that wellestablished ADRD genetic risk factors for Caucasian populations including APOE, APP, PSEN1, and PSEN2 have not been studied to the same degree in minority U.S. populations. The APOE genotype has been shown to be less predictive of ADRD risk in African American, Asian American, Hispanic American, and Native American populations (26, 27, 29, 98). Other genetic risk factors may play a larger role in ADRD genetic risk in these populations, with potential candidates including genes with various functions such as ABCA7, CLU, CR1, PICALM, SORL1, AKAP9, and TREM2 $(26,27,29,98,109)$. These genes were noted in our review, however with far less frequency than $A P O E$. Preliminary findings indicate that there may be a more complex
TABLE 2 | Type of ADRD and risk genes identified in full-text review articles $(N=66)$.

\begin{tabular}{|c|c|c|}
\hline Characteristic & Number & Percentage (\%) \\
\hline \multicolumn{3}{|l|}{ Type of ADRD ${ }^{a}$} \\
\hline Lewy Body Dementia & 1 & 1.5 \\
\hline Mild Cognitive Impairment & 2 & 3.0 \\
\hline Cognitive Decline & 2 & 3.0 \\
\hline Vascular Dementia & 4 & 6.1 \\
\hline Early onset AD (EOAD) & 7 & 10.6 \\
\hline Alzheimer's Disease & 13 & 19.7 \\
\hline Type of ADRD not specified & 20 & 30.3 \\
\hline Late Onset AD (LOAD) & 26 & 39.4 \\
\hline \multicolumn{3}{|l|}{ ADRD risk genes identified ${ }^{b}$} \\
\hline PSEN2 & 1 & 1.5 \\
\hline AKAP9 & 2 & 3.0 \\
\hline GRIN3B & 2 & 3.0 \\
\hline SORL1 & 2 & 3.0 \\
\hline CR1 & 3 & 4.5 \\
\hline APP & 4 & 6.1 \\
\hline PSEN1 & 4 & 6.1 \\
\hline ABCA7 & 6 & 9.1 \\
\hline CLU & 6 & 9.1 \\
\hline PICALM & 7 & 10.6 \\
\hline APOE & 43 & 65.2 \\
\hline Other & 42 & 63.6 \\
\hline
\end{tabular}

a Some articles examined more than one type of ADRD. ${ }^{b}$ Some articles included multiple risk genes.

polygenic profile of ADRD genetic risk in these populations, and this has potential implications for the possible polygenic nature of ADRD risk in all populations $(27,59,87)$.

In comparison to the amount of research that has been conducted on Caucasians in the U.S., we found that some minority communities were vastly underrepresented in the research, namely Hispanics, Native Americans, and Asian Americans. Though the number of studies on ADRD genetic risk factors in minority populations has increased over time, especially for certain populations such as African Americans, more comprehensive studies with large sample sizes should be performed to establish key genetic risk factors for these populations as well $(27,109-112)$. Among the studies in our review, sample size for non-GWAS studies started as low as $N$ $=19$ for a case report design. As the sample size increases and more diverse persons are included, additional, more statistically sound conclusions can be made about the associations between genetic expression and disease outcome.

Additionally, comparative studies with both minority and majority population group samples would be useful in examining genetic risk factors, as well as the effects of environment and other factors. Studies exploring genetic risk factors in these populations is warranted to determine the role that both genes and environmental factors play in increased ADRD risks in these populations. A larger, systematic review of existing literature on genetic risk factors for minority U.S. populations would be 
TABLE 3 | Detailed listing of studies included in the full-text review.

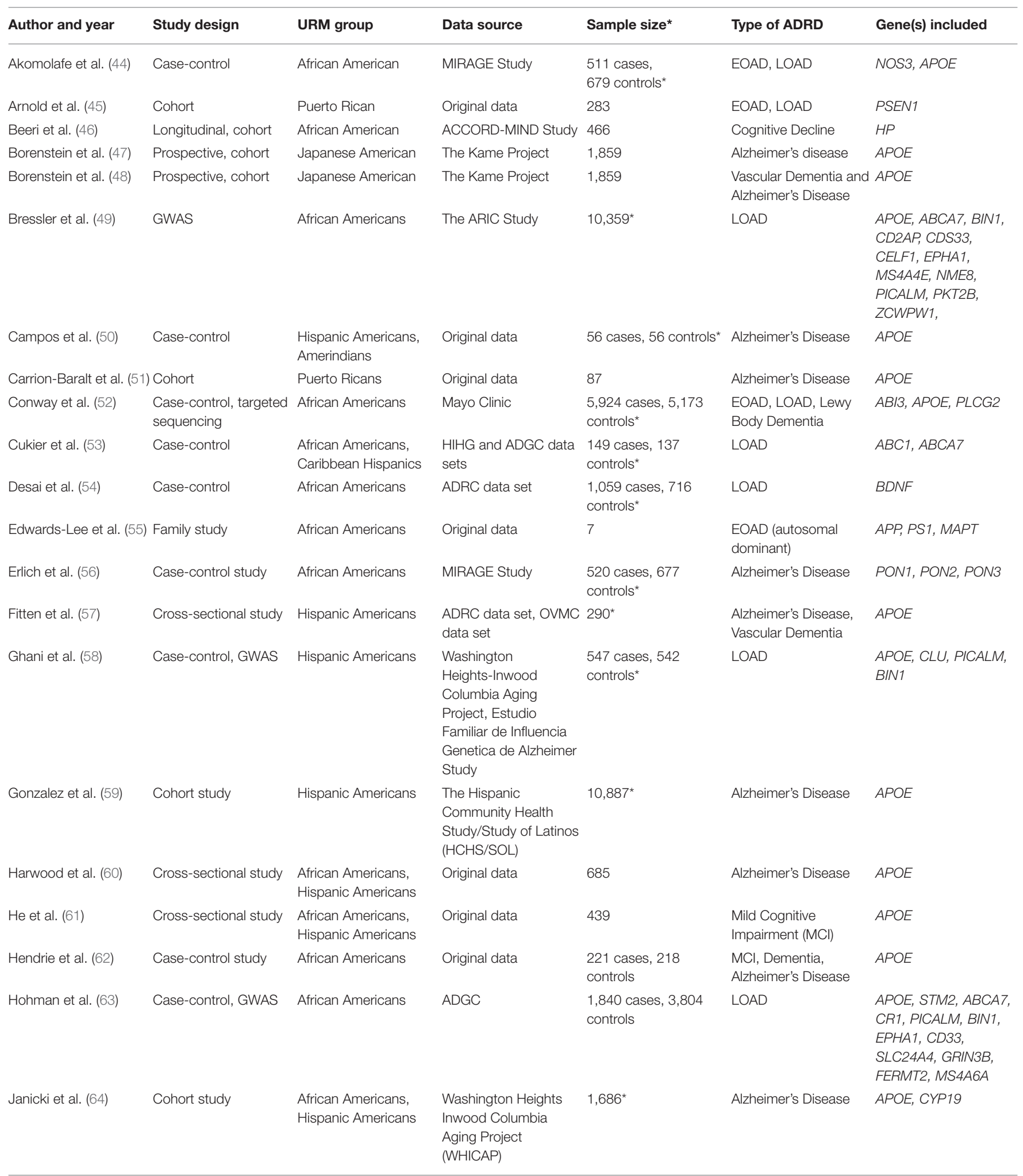


TABLE 3 | Continued

\begin{tabular}{|c|c|c|c|c|c|c|}
\hline Author and year & Study design & URM group & Data source & Sample size* & Type of ADRD & Gene(s) included \\
\hline Jin et al. (65) & Case-control & African Americans & $\begin{array}{l}\text { Knight-ADRC + } \\
\text { NIA-LOAD, Mayo } \\
\text { Clinic, Indiana } \\
\text { University, WHICAP, } \\
\text { Emory University }\end{array}$ & $\begin{array}{l}906 \text { cases, } 2,487 \\
\text { controls* }^{\star}\end{array}$ & LOAD & TREM2 \\
\hline Janicki et al. (66) & $\begin{array}{l}\text { Prospective Cohort } \\
\text { study }\end{array}$ & $\begin{array}{l}\text { African Americans, } \\
\text { Hispanic Americans }\end{array}$ & WHICAP & $1,686^{*}$ & Alzheimer's Disease & ESR1 \\
\hline Kuller et al. (68) & $\begin{array}{l}\text { Longitudinal cohort } \\
\text { study }\end{array}$ & African Americans & $\begin{array}{l}\text { Pittsburgh } \\
\text { Cardiovascular Health } \\
\text { Study }\end{array}$ & 532 & LOAD & $A P O E$ \\
\hline Kwon et al. (70) & Cohort study & $\begin{array}{l}\text { African Americans, } \\
\text { Hispanic Americans }\end{array}$ & Original data & $1,309^{*}$ & LOAD & $A P O E$ \\
\hline Lee et al. (71) & $\begin{array}{l}\text { Nested Case-control } \\
\text { study, prospective }\end{array}$ & $\begin{array}{l}\text { African Americans, } \\
\text { Hispanic Americans }\end{array}$ & Original data & $\begin{array}{l}296 \text { cases, } 428 \\
\text { controls }^{\star}\end{array}$ & $A D$ & SORL1 \\
\hline Lee et al. (72) & $\begin{array}{l}\text { Family-based cohort } \\
\text { study, GWAS }\end{array}$ & Caribbean Hispanic & Original data & $\begin{array}{l}1,161 \text { individuals from } \\
209 \text { families }\end{array}$ & Familial LOAD & $\begin{array}{l}\text { APOE, PSEN1, 5q15, } \\
7 q 36.3,14 q 32.12 \\
17 q 25.1,17 p 13\end{array}$ \\
\hline Lee (75) & $\begin{array}{l}\text { Family-based cohort } \\
\text { study }\end{array}$ & Caribbean Hispanics & $\begin{array}{l}\text { WHICAP and EFIGA } \\
\text { datasets }\end{array}$ & 2,888 & EOAD, LOAD & $\begin{array}{l}\text { PSEN1, SNX25, } \\
\text { PDLIM3, SORBS2, } \\
\text { SH3RF3, NPHP1 }\end{array}$ \\
\hline Livney (76) & Cross-sectional study & $\begin{array}{l}\text { African American, } \\
\text { Hispanic Americans }\end{array}$ & Original data & 1,341 & $A D$ & $A P O E$ \\
\hline Logue (77) & Case-control study & African Americans & $\begin{array}{l}\text { MIRAGE, } \\
\text { GenerAAtions, ADNI, } \\
\text { GenADA, NIA-LOAD, } \\
\text { FHS }\end{array}$ & $\begin{array}{l}\text { 3,568 cases, 6,205 } \\
\text { controls* }\end{array}$ & & $\begin{array}{l}\text { APOE, PVRL2, CLU, } \\
\text { PICALM, BIN1, EPHA1, } \\
\text { MS4A, ABCA7, and } \\
\text { CD33, TOMM4O }\end{array}$ \\
\hline Logue et al. (78) & Case-control & African Americans & $\begin{array}{l}\text { MIRAGE Study, } \\
\text { GenerAAtions Study }\end{array}$ & $\begin{array}{l}422 \text { cases, } 394 \\
\text { controls }\end{array}$ & EOAD, LOAD & $\begin{array}{l}\text { AKAP9, APOE, BIN1, } \\
\text { CLU, CR1, PICALM, } \\
\text { MS4A6E, CD2AP, } \\
\text { CD33, ABCA7, EPHA1, } \\
\text { SORL1, ACE, PSEN1, } \\
\text { PSEN2, APP }\end{array}$ \\
\hline
\end{tabular}


TABLE 3 | Continued

\begin{tabular}{|c|c|c|c|c|c|c|}
\hline Author and year & Study design & URM group & Data source & Sample size ${ }^{\star}$ & Type of ADRD & Gene(s) included \\
\hline Logue et al. (79) & Case-control & African Americans & $\begin{array}{l}\text { MIRAGE Study, } \\
\text { GenerAAtions Study, } \\
\text { National Cell } \\
\text { Repository for } \\
\text { Alzheimer's Disease } \\
\text { (NCRAD), } \\
\text { Ibadan/Indianapolis } \\
\text { (INDY) Study }\end{array}$ & $\begin{array}{l}489 \text { cases, } 472 \\
\text { controls }\end{array}$ & LOAD & $\begin{array}{l}\text { ABCA7, AKAP9, } \\
\text { KIAA0196, KANSL1, } \\
\text { CNN2, TRIM2 }\end{array}$ \\
\hline Marden et al. (80) & Cohort & African Americans & $\begin{array}{l}\text { Health and Retirement } \\
\text { Study (HRS) }\end{array}$ & $7,690^{\star}$ & $A D$ and Dementia & $\begin{array}{l}\text { APOE, BIN1, CLU, } \\
\text { ABCA7, CR1, PICALM, } \\
\text { MS4A6A, CD33, } \\
\text { MS4A4E, CD2AP }\end{array}$ \\
\hline Marden et al. (81) & Cohort & African Americans & HRS & $8,253^{*}$ & $A D$ & $\begin{array}{l}\text { APOE, CLU, CR1, } \\
\text { PICALM }\end{array}$ \\
\hline Mez et al. (84) & Case-control & African Americans & $\begin{array}{l}\text { ADGC, GenerAAtions, } \\
\text { MIRAGE, CHAP }\end{array}$ & $\begin{array}{l}1,825 \text { cases, } 3,784 \\
\text { controls }\end{array}$ & LOAD & $\begin{array}{l}\text { APOE, ABCA7, COBL, } \\
\text { SLC10A2 }\end{array}$ \\
\hline Mount et al. (85) & $\begin{array}{l}\text { Cross-sectional, } \\
\text { retrospective }\end{array}$ & African Americans & ADCR & 65 & LOAD & $A P O E$ \\
\hline Murrell et al. (86) & Cohort & African Americans & Original data & 480 & LOAD & $A P O E$ \\
\hline N'Songo et al. (87) & Cohort & African Americans & Original data & $\begin{array}{l}198 \text { cases, } 350 \\
\text { controls }\end{array}$ & EOAD & APP, PSEN1, PSEN2 \\
\hline O’Bryant et al. (88) & Cohort & Mexican Americans & $\begin{array}{l}\text { Project } \\
\text { FRONTIER, TARCC }\end{array}$ & 1,628 & $\mathrm{MCl}$ & APOE \\
\hline O’Bryant et al. (89) & Cohort, CBPR & Mexican Americans & $\begin{array}{l}\text { Project } \\
\text { FRONTIER, TARCC }\end{array}$ & $1,069^{*}$ & $\mathrm{MCl}, \mathrm{AD}$ & $A P O E$ \\
\hline Peila et al. (92) & Nested case-control & Japanese-Americans & $\begin{array}{l}\text { Honolulu-Asia Aging } \\
\text { Study (HAAS), Honolulu } \\
\text { Heart Program (HHP) }\end{array}$ & $\begin{array}{l}283 \text { cases, } 573 \\
\text { controls }\end{array}$ & AD, Vascular Dementia & $A P O E, T G F-\beta 1$ \\
\hline Petrovich et al. (93) & Longitudinal, cohort & Japanese-Americans & $\begin{array}{l}\text { The Honolulu-Asia } \\
\text { Aging Study }\end{array}$ & 375 & $A D$ & APOE \\
\hline Qian et al. (94) & Prospective, cohort & Latinos & $\begin{array}{l}\text { NACC, Rotterdam } \\
\text { Study, Framingham } \\
\text { Heart Study, and } \\
\text { Sacramento Area } \\
\text { Latino Study (SALSA) }\end{array}$ & $16,844^{\star}$ & $A D$ & $A P O E$ \\
\hline Rajabli et al. (95) & Case-control & $\begin{array}{l}\text { African Americans, } \\
\text { Hispanic Americans }\end{array}$ & $\begin{array}{l}\text { HGDP (Human } \\
\text { Genome Diversity } \\
\text { Project) }\end{array}$ & $\begin{array}{l}1,986 \text { cases, 3,899 } \\
\text { controls* }\end{array}$ & LOAD & $A P O E$ \\
\hline Reitz et al. (96) & Case-control & $\begin{array}{l}\text { African Americans and } \\
\text { Caribbean Hispanics }\end{array}$ & $\begin{array}{l}\text { Toronto dataset, } \\
\text { NIA-LOAD, MIRAGE } \\
\text { Caucasian dataset, } \\
\text { MIRAGE African } \\
\text { American dataset, } \\
\text { Miami Caucasian, } \\
\text { Caribbean Hispanic } \\
\text { dataset }\end{array}$ & $\begin{array}{l}2,809 \text { cases, } 3,482 \\
\text { controls }\end{array}$ & $A D$ & $\begin{array}{l}\text { SORCS1, APP, AB, } \\
\text { SORL1 }\end{array}$ \\
\hline
\end{tabular}


TABLE 3 | Continued

\begin{tabular}{|c|c|c|c|c|c|c|}
\hline Author and year & Study design & URM group & Data source & Sample size* & Type of ADRD & Gene(s) included \\
\hline Reitz et al. (97) & Case-control & Caribbean Hispanics & $\begin{array}{l}\text { DMS-IV, } \\
\text { NINCDS-ADRDA }\end{array}$ & $\begin{array}{l}160 \text { cases, } 294 \\
\text { controls }\end{array}$ & LOAD & IDE, KIF1, HHEX \\
\hline Rippon et al. (99) & $\begin{array}{l}\text { Family-based cohort } \\
\text { study }\end{array}$ & Latinos & NINDCS-ADRDA & 1,498 & Familial AD & $A P O E$ \\
\hline Sacyzynsky et al. (101) & Cohort & Japanese-Americans & $\begin{array}{l}\text { The Honolulu Heart } \\
\text { Program, Cooperative } \\
\text { Lipoprotein Study }\end{array}$ & 929 & Dementia & $A P O E$ \\
\hline Sawyer et al. (102) & Prospective cohort & African Americans & Duke EPESE Study & $2,076^{\star}$ & Cognitive decline (CD) & $A P O E$ \\
\hline Vardarajan et al. (105) & Case-control & African Americans & ADGC & $\begin{array}{l}8,309 \text { cases, } 7,366 \\
\text { controls* }^{*}\end{array}$ & $A D$ & $\begin{array}{l}\text { APP, KIAA1033, SNX1, } \\
\text { SORL1, SNX3, RAB7A }\end{array}$ \\
\hline Vardarajan et al. (106) & $\begin{array}{l}\text { Family and } \\
\text { cohort-based genetic } \\
\text { association study }\end{array}$ & Caribbean Hispanics & Original data & $\begin{array}{l}464 \text { familial } \\
\text { subjects }-(350 \\
\text { affected, } 114 \\
\text { unaffected), } 498 \\
\text { unrelated controls }\end{array}$ & LOAD & SORL1 \\
\hline Weiner et al. (107) & Case-control & Choctaw Indians & $\begin{array}{l}\text { Original data (Choctaw } \\
\text { Indians) and UT } \\
\text { Southwestern } \\
\text { Alzheimer's Disease } \\
\text { Center (ADC) }\end{array}$ & 78 cases, 39 controls* & $A D$ & $A P O E$ \\
\hline
\end{tabular}

${ }^{*}$ Article included multiple races/ethnicities in the study sample.

an appropriate next step in better understanding the existing study landscape with intentions toward implementing GWAS and meta-analyses for diverse U.S. populations.

Knowledge gaps in the disease mechanism among racial/ethnic minority populations is a critical indicator of inequities in genetics and genomics research in these communities, as well as a lack of equity in the health care system for these groups (112). Advancements in genetic medicine and genomic research proliferate, unfortunately not at the same rate for all persons. The impact that disproportionate expansion, innovation, and progress in the field can have on health disparities is significant $(12,112)$. With that in mind, it is also important to acknowledge that while genetic inquiry is crucial to understanding the disparities present in ADRD, it is not the sole risk factor. Other factors such as environment and socio-environmental context, are implicated in the distribution of racial health disparities, and in fact, the complex interplay of all these factors contribute to many disease outcomes $(12,113,114)$.
Of additional consideration as an important implication of this research, particularly for minority populations, is the potential of stigma related to ADRD diagnosis. Some groups have been found to consider dementia as a normal part of aging (115), while others may find shame in an AD diagnosis or the need to keep such health information private (116-118). We highlight these studies as further evidence of the need to focus research in racially and ethnically diverse communities. Furthermore, we acknowledge that such research should consider both quantitative and qualitative approaches.

This study is not without limitations. First, while we conducted a systematic and structured process for the scoping review, we did not evaluate the quality of the evidence presented or the authors' research methods as part of this review. Second, some studies more clearly identified the characteristics of interest for our review than others, and as such, some of the data presented was left to the interpretation of the authorship team. Third, we acknowledge that there is limited generalizability of our findings to research that has been conducted in the U.S. among 
racial/ethnic minorities. That said, we find that an important strength of this review is in identifying the knowledge gaps in examining and understanding the genetic factors associated with ADRD among racial/ethnic minority populations, which is of growing disease and economic burden in the U.S.

\section{CONCLUSION}

Based our findings, we recommend that additional studies be undertaken to map out and more deeply explore ADRD genetic risk factors among racial/ethnic minority populations in the U.S. at levels comparable to non-minority populations. An increased number of larger scale studies of racially/ethnically diverse persons can aid researchers in making more powerful conclusions about genetic associations in ADRD among populations most affected. Examining genetic risk factors for ADRDs in minority populations can deepen our understanding of the interaction between biological or genetic factors and socioecological determinants of health. Furthermore, understanding the role of genetic predisposing factors has the potential to increase preventive health measures and screening, which could lead to reduced time to diagnosis and improved ADRD disease management. Lastly, ethical concerns about the impact that this

\section{REFERENCES}

1. Alzheimer's Association Report: 2020 Alzheimer's Disease Facts and Figures. Alzheimers Dement. (2020). 16:391-460. doi: 10.1002/alz.12068

2. Hebert LE, Weuve J, Scherr PA, Evans DA. Alzheimer disease in the United States (2010-2050) estimated using the 2010 census. Neurology. (2013). 80:1778-83. doi: 10.1212/WNL.0b013e31828726f5

3. Matthews KA, Xu W, Gaglioti AH, Holt JB, Croft JB, Mack D, et al. Racial and Ethnic Estimates of Alzheimer's Disease and Related Dementias in the United States (2015-2060) in Adults Aged $\geq 65$ years. Alzheimers Dement. (2019) 15:17-24. doi: 10.1016/j.jalz.2018.06.3063

4. Chen C, Zissimopoulos JM. Racial and ethnic differences in trends in dementia prevalence and risk factors in the United States. Alzheimers Dement. (2018) 4:510-20. doi: 10.1016/j.trci.2018.08.009

5. Steenland K, Goldstein FC, Levey A, Wharton W. A meta-analysis of Alzheimer's disease incidence and prevalence comparing African-Americans and Caucasians. J Alzheimers Dis. (2016) 50:71-6. doi: 10.3233/JAD150778

6. Colby SL, Ortman JM. Projections of the size and composition of the U.S. population: 2014 to 2060. Population estimates and projections: current population reports. Washington, DC: US Census Bureau (2015). Available online at: http://www.census.gov/content/dam/Census/library/publications/ 2015/demo/p25-1143.pdf (accessed March 22, 2021).

7. Shin J, Doraiswamy PM. Underrepresentation of African Americans in Alzheimer's trials: a call for affirmative action. Front Aging Neurosci. (2016) 8:123. doi: 10.3389/fnagi.2016.00123

8. Quiñones AR, Kaye J, Allore HG, Botoseneanu A, Thielke SM. An agenda for addressing multimorbidity and racial and ethnic disparities in Alzheimer's disease and related dementia. Am J Alzheimers Dis Other Demen. (2020) 35:153331752096087. doi: 10.1177/1533317520960874

9. Peterson RL, Fain MJ, Butler AE, Ehiri JE, Carvajal SC. The role of social and behavioral risk factors in explaining racial disparities in age-related cognitive impairment: a structured narrative review. Aging, Neuropsychol Cogn. (2019) 27:173-96. doi: 10.1080/13825585.2019.1598539

10. Weuve J, Barnes LL, Mendes de Leon CF, Rajan KB, Beck T, Aggarwal NT, et al. Cognitive aging in black and white Americans. Epidemiology. (2018) 29:151-9. doi: 10.1097/EDE.0000000000000747 knowledge of genetic risk factors may have on the health and well-being of individuals must be addressed as we continue to obtain more data on these genetic factors. As our population ages and the size of our minority populations increase in the U.S., understanding the burden of ADRD on our aging populations can aid in providing insight into the most appropriate and effective public health actions.

\section{DATA AVAILABILITY STATEMENT}

The original contributions presented in the study are included in the article/supplementary material, further inquiries can be directed to the corresponding author/s.

\section{AUTHOR CONTRIBUTIONS}

LR conceptualized the study, was a scoping reviewer, and contributed to the manuscript narrative. LI and DF were scoping reviewers, contributed to the manuscript narrative, and helped to edit the manuscript. NR was a scoping reviewer and contributed to the manuscript narrative. BA-C, AR, KL, SU, and QM were scoping reviewers and helped to edit the manuscript. All authors contributed to the article and approved the submitted version.

11. Zuelsdorff M, Okonkwo OC, Norton D, Barnes LL, Graham KL, Clark LR, et al. Stressful life events and racial disparities in cognition among middle-aged and older adults. J Alzheimers Dis. (2020) 73:67182. doi: 10.3233/JAD-190439

12. Froehlich TE, Bogardus ST Jr, Inouye SK. Dementia and race: are there differences between African Americans and Caucasians?. J Am Geriatr Soc. (2001) 49:477-84. doi: 10.1046/j.1532-5415.2001.49096.x

13. Martin AR, Kanai M, Kamatani Y, Okada Y, Neale BM, Daly MJ. Clinical use of current polygenic risk scores may exacerbate health disparities. Nat Genet. (2019) 51:584-91. doi: 10.1038/s41588-019-0379-x

14. Moonesinghe R, Jones W, Honoré PA, Truman BI, Graham G. Genomic medicine and racial/ethnic health disparities: promises, perils, and the challenges for health care and public health policy. Ethn Dis. (2009) 19:473-8.

15. Hunt LM, Megyesi MS. Genes, race and research ethics: who's minding the store?. J Med Ethics. (2008) 34:495-500. doi: 10.1136/jme.2007.021295

16. Lee SS. Pharmacogenomics and the challenge of health disparities. Publ Health Genomics. (2009) 12:170-9. doi: 10.1159/000189630

17. Rotimi CN. Are medical and nonmedical uses of large-scale genomic markers conflating genetics and 'race'?. Nat Genet. (2004) 36(11 Suppl):S437. doi: $10.1038 /$ ng 1439

18. Scharff DP, Mathews KJ, Jackson P, Hoffsuemmer J, Martin E, Edwards D. More than Tuskegee: understanding mistrust about research participation. J Health Care Poor Underserved. (2010) 21:879-97. doi: 10.1353/hpu.0.0323

19. Berg CN, Sinha N, Gluck MA. The effects of APOE and ABCA7 on cognitive function and Alzheimer's disease risk in African Americans: a focused mini review. Front Hum Neurosci. (2019) 13:387. doi: 10.3389/fnhum.2019.00387

20. Potter H, Wisniewski T. Apolipoprotein E: essential catalyst of the Alzheimer amyloid cascade. Int J Alzheimers Dis. (2012) 2012:489428. doi: 10.1155/2012/489428

21. Bertram L, McQueen MB, Mullin K, Blacker D, Tanzi RE. Systematic meta-analyses of Alzheimer disease genetic association studies: the AlzGene database. Nat Genet. (2007) 39:17-23. doi: 10.1038/ng1934

22. Bertram L, Tanzi RE. Alzheimer disease risk genes: 29 and counting. Nat Rev Neurol. (2019) 15:191-2. doi: 10.1038/s41582-019-0158-4

23. Cacace R, Sleegers K, Van Broeckhoven C. Molecular genetics of earlyonset Alzheimer's disease revisited. Alzheimers Dement. (2016) 12:73348. doi: 10.1016/j.jalz.2016.01.012 
24. Roberts JS, Patterson AK, Uhlmann WR. Genetic testing for neurodegenerative diseases: Ethical and health communication challenges. Neurobiol Dis. (2020) 141:104871. doi: 10.1016/j.nbd.2020.104871

25. Elston RC, Satagopan JM, Sun S. Genetic terminology. Methods Mol Biol. (2012) 850:1-9. doi: 10.1007/978-1-61779-555-8_1

26. Graff-Radford NR, Besser LM, Crook JE, Kukull WA, Dickson DW. Neuropathologic differences by race from the National Alzheimer's Coordinating Center. Alzheimers Dement. (2016) 12:669-77. doi: 10.1016/j.jalz.2016.03.004

27. Heffernan AL, Chidgey C, Peng P, Masters CL, Roberts BR. The neurobiology and age-related prevalence of the $\varepsilon 4$ allele of apolipoprotein E in Alzheimer's Disease Cohorts. J Mol Neurosci. (2016) 60:31624. doi: 10.1007/s12031-016-0804-x

28. Mez J, Marden JR, Mukherjee S, Brewster P, Hamilton JL, Gilsanz P, et al. P2-076: Alzheimer's disease genetic risk variants beyond Apoe $\varepsilon 4$ predict mortality in the adult changes in thought (ACT) study. Alzheimers Dement. (2016) 12:P637-8. doi: 10.1016/j.jalz.2016.06.1281

29. Berkowitz CL, Mosconi L, Rahman A, Scheyer O, Hristov H, Isaacson RS. Clinical application of APOE in Alzheimer's prevention: a precision medicine approach. J Prev Alzheimers Dis. (2018) 5:245-52. doi: 10.14283/jpad.2018.35

30. Tang M-X, Stern Y, Marder K, Bell K, Gurland B, Lantigua R, et al. The APOE-epsilon4 allele and the risk of Alzheimer disease among African Americans, whites, and Hispanics. JAMA. (1998) 279:7515. doi: 10.1001/jama.279.10.751

31. Huang $M$, Wang $D, X u Z, X u Y, X u X, M a ~ Y$, et al. Lack of genetic association between TREM2 and Alzheimer's disease in East Asian population: a systematic review and meta-analysis. Am J Alzheimers Dis Other Dement. (2015) 30:541-6. doi: 10.1177/1533317515577128

32. Huq AJ, Fransquet P, Laws SM, Ryan J, Sebra R, Masters CL, et al. Genetic resilience to Alzheimer's disease in APOE $\varepsilon 4$ homozygotes: a systematic review. Alzheimers Dement. (2019) 15:1612-23. doi: 10.1016/j.jalz.2019.05.011

33. Sanghvi H, Singh R, Morrin H, Rajkumar AP. Systematic review of genetic association studies in people with Lewy Body Dementia. Int $J$ Geriatr Psychiatry. (2020) 35:436-48. doi: 10.1002/gps.5260

34. Andrews SJ, McFall GP, Booth A, Dixon RA, Anstey KJ. Association of Alzheimer's disease genetic risk loci with cognitive performance and decline: a systematic review. J Alzheimers Dis. (2019) 69:110936. doi: 10.3233/JAD-190342

35. Arksey H, O'Malley L. Scoping studies: towards a methodological framework. Int J Soc Res Methodol. (2005) 8:19-32. doi: 10.1080/1364557032000119616

36. Peters MD, Godfrey CM, Khalil H, McInerney P, Parker D, Soares CB. Guidance for conducting systematic scoping reviews. Int J Evid Based Healthc. (2015) 13:141-6. doi: 10.1097/XEB.0000000000000050

37. Friedman DB, Becofsky K, Anderson LA, Bryant LL, Hunter RH, Ivey SL, et al. Public perceptions about risk and protective factors for cognitive health and impairment: a review of the literature. Int Psychogeriatr. (2015) 27:1263-75. doi: 10.1017/S1041610214002877

38. Resciniti NV, Tang W, Tabassum M, Pearson JL, Spencer SM, Lohman $\mathrm{MC}$, et al. Knowledge evaluation instruments for dementia caregiver education programs: a scoping review. Geriatr Gerontol Int. (2020) 20:397413. doi: 10.1111/ggi.13901

39. Tricco AC, Lillie E, Zarin W, O’Brien KK, Colquhoun H, Levac D, et al. Prisma Extension for Scoping Reviews (PRISMA-SCR): checklist and explanation. Ann Intern Med. (2018) 169:467-73. doi: 10.7326/M18-0850

40. Grant MJ, Booth A. A typology of reviews: an analysis of 14 review types and associated methodologies. Health Info Libr J. (2009) 26:91108. doi: 10.1111/j.1471-1842.2009.00848.x

41. Ureña S, Ingram LA, Leith $\mathrm{K}$, Lohman MC, Resciniti N, Rubin L, et al. Mentorship and training to increase diversity of researchers and practitioners in the field of aging and Alzheimer's disease: a scoping review of program characteristics. J Aging Health. (2021) 33:4862. doi: 10.1177/0898264320953345

42. Tanzi RE, Bertram L. New frontiers in Alzheimer's disease genetics. Neuron. (2001) 32:181-4. doi: 10.1016/S0896-6273(01)00476-7
43. Kilpinen $\mathrm{H}$, Barrett JC. How next-generation sequencing is transforming complex disease genetics. Trends Genet. (2013) 29:23-30. doi: 10.1016/j.tig.2012.10.001

44. Akomolafe A, Lunetta KL, Elrich PM, Cupples, LA, Baldwin CT, Huyck $M$, et al. Genetic association between endothelial nitric oxide synthase and Alzheimer disease. Clin Genet. (2006) 70:49-56. doi: 10.1111/j.1399-0004.2006.00638.x

45. Arnold SE, Vega IE, Karlawish JH, Wolk DA, Nunez J, Negron M, et al. Frequency and clinicopathological characteristics of presenilin 1 Gly206Ala mutation in Puerto Rican Hispanics with dementia. J Alzheimers Dis. (2013) 33:1089-95. doi: 10.3233/JAD-2012-121570

46. Beeri MS, Lin HM, Sano M, Springer RR, Liu X, Bendlin BB, et al. Association of the haptoglobin gene polymorphism with cognitive function and decline in elderly african american adults with type 2 diabetes: findings from the action to control cardiovascular risk in diabetes-memory in diabetes (accord-mind) study. JAMA Netw Open. (2018) 7:e184458. doi: 10.1001/jamanetworkopen.2018.4458

47. Borenstein AR, Wu Y, Mortimer JA, Schellenberg GD, McCormick WC, Bowen JD, et al. Developmental and vascular risk factors for Alzheimer's disease. Neurobiol Aging. (2005) 26:325-34. doi: 10.1016/j.neurobiolaging.2004.04.010

48. Borenstein AR, Wu Y, Bowen JD, McCormick WC, Uomoto J, McCurry SM, et al. Incidence rates of dementia, Alzheimer disease, and vascular dementia in the Japanese American population in Seattle, WA: the Kame Project. Alzheimer Dis Assoc Disord. (2014) 28:23-9. doi: 10.1097/WAD.0b013e3182a2e32f

49. Bressler J, Mosley TH, Penman A, Gottesman RF, Windham BG, Knopman DS,et al. Genetic variants associated with risk of Alzheimer's disease contribute to cognitive change in midlife: The atherosclerosis risk in communities study. Am J Med Genet B Neuropsychiatr Genet. (2017) 174:269-82. doi: 10.1002/ajmg.b.32509

50. Campos M, Edlan S, Peavy G. An exploratory study of APOE- $\varepsilon 4$ genotype and risk of Alzheimer's disease in Mexican Hispanics. J Am Geriatr Soc. (2013) 61:1038-y40. doi: 10.1111/jgs.12292

51. Carrión-Baralt J, Meléndez-Cabrero J, Rodríguez-Ubiñas H, Schmeidler J, Beei M, Angelo G, et al. Impact of APOE $\varepsilon 4$ on the cognitive performance of a sample of non-demented Puerto Rican Nonagenarians. J Alzheimer Dis. (2009) 18:533-40. doi: 10.3233/JAD-2009-1160

52. Conway O, Carrasquillo M, Wang X, Bredenberg J, Reedy J, Strickland S, et al. ABI3 and PLCG2 missense variants as risk factors for neurodegenerative diseases in Caucasians and African Americans. Mol. Neurodegener. (2018) 13. doi: 10.1186/s13024-018-0289-x

53. Cukier H, Kunkle B, Vardarajan B, Rolati S, Hamilton-Nelson $\mathrm{K}$, Kohli $\mathrm{M}$, et al. ABCA7 frameshift deletion associated with Alzheimer disease in African Americans. Neurol. Genet. (2016) 2:34-8. doi: 10.1212/NXG.0000000000000079

54. Desai P, DeKosky S, Kamboh I. Genetic variation in the cholesterol 24hydroxylase (CYP46) gene and the risk of Alzheimer's disease. Neurosci. Lett. (2002) 328:9-12. doi: 10.1016/s0304-3940(02)00443-3

55. Edwards-Lee T, Ringman JM, Chung J, Werner J, Morgan A, Hyslop $G$, et al. An African American family with early-onset Alzheimer disease and an APP (T714I) mutation. Neurology. (2005) 64:23. doi: 10.1212/01.WNL.0000149761.70566.3E

56. Elrich P, Lunetta K, Cupples A, Huyck M, Green R, Baldwin C, et al. Polymorphisms in the PON gene cluster are associated with Alzheimer disease. Hum Mol Genet. (2006) 15:77-85. doi: 10.1093/hmg/ddi428

57. Fitten J, Ortiz F, Fairbanks L, Bartzokis G, Lu P, Klein E, et al. Younger age of dementia diagnosis in a Hispanic population in southern California. Int $J$ Geriatr. (2014) 29:586-93. doi: 10.1002/gps.4040

58. Ghani M, Sato C, Lee J, Reitz C, Moreno D, Mayeux R, et al. Evidence of recessive Alzheimer disease loci in a Caribbean Hispanic data set: Genomewide survey of runs of homozygosity. JAMA Neurol. (2013) 70:1261-7. doi: 10.1001/jamaneurol.2013.3545

59. González HM, Tarraf W, Jian X, Vasquez PM, Kaplan R, Thyagarajan B, et al. Apolipoprotein $\mathrm{E}$ genotypes among diverse middle-aged and older latinos: study of latinos-investigation of neurocognitive aging results (HCHS/SOL). Sci Rep. (2018) 8:17578. doi: 10.1038/s41598-018-35573-3 
60. Harwood DG, Kalechstein A, Barker WW, et al. The effect of alcohol and tobacco consumption, and apolipoprotein E genotype, on the age of onset in Alzheimer's disease. Int J Geriatr Psychiatry. (2010) 25:511-8. doi: 10.1002/gps.2372

61. He J, Farias S, Martinez O, Reed B, Mungas D, Decarli C. Differences in brain volume, hippocampal volume, cerebrovascular risk factors, and apolipoprotein E4 among mild cognitive impairment subtypes. Arch Neurol. (2009) 66:1393-9. doi: 10.1001/archneurol.2009.252

62. Hendrie HC, Murrell J, Baiyewu O, Lane KA, Purnell C, Ogunniyi A, et al. APOE $\varepsilon 4$ and the risk for Alzheimer disease and cognitive decline in African Americans and Yoruba. Int Psychogeriatr. (2014) 26:977-85. doi: $10.1017 /$ S1041610214000167

63. Hohman TJ, Cooke-Bailey JN, Reitz C, Jun G, Naj A, Beecham GW, et al. Global and local ancestry in African-Americans: Implications for Alzheimer's disease risk. Alzheimers Dement. (2016) 12:233-43. doi: 10.1016/j.jalz.2015.02.012

64. Janicki SC, Park N, Cheng R, Schupf N, Clark LN, Lee JH. Aromatase variants modify risk for Alzheimer's disease in a multiethnic female cohort. Dement Geriatr Cogn Disord. (2013) 35:340-6. doi: 10.1159/000343074

65. Janicki SC, Park N, Cheng R, Clark LN, Lee JH, Schupf N. Estrogen receptor $\alpha$ variants affect age at onset of Alzheimer's disease in a multiethnic female cohort. Dement Geriatr Cogn Disord. (2014) 38:200-13. doi: 10.1159/000355559

66. Jin SC, Carrasquillo MM, Benitez BA, Tara S, Carrell D, Patel $\mathrm{D}$, et al. TREM2 is associated with increased risk for Alzheimer's disease in African Americans. Mol Neurodegener. (2015) 10:19. doi: 10.1186/s13024-015-0016-9

67. Kim S, Nho K, Ramanan VK, Lai D, Foroud TM, Lane K, et al. Genetic Influences on Plasma Homocysteine Levels in African Americans and Yoruba Nigerians. J Alzheimers Dis. (2016) 49:991-1003. doi: 10.3233/JAD-150651

68. Kuller LH, Lopez OL, Becker JT, Chang Y, Newman AB. Risk of dementia and death in the long-term follow-up of the Pittsburgh Cardiovascular Health Study-Cognition Study. Alzheimers Dement. (2016) 12:170-83. doi: 10.1016/j.jalz.2015.08.165

69. Kunkle BW, Carney RM, Kohli MA, Naj AC, Nelson KLH, Whitehead PL, et al. Targeted sequencing of ABCA7 identifies splicing, stop-gain and intronic risk variants for Alzheimer disease. Neurosci Lett. (2017) 649:124-9. doi: 10.1016/j.neulet.2017.04.014

70. Kwon OD, Khaleeq A, Chan W, Pavlik VN, Doody RS. Apolipoprotein E polymorphism and age at onset of Alzheimer's disease in a quadriethnic sample. Dement Geriatr Cogn Disord. (2010) 30:486-91. doi: $10.1159 / 000322368$

71. Lee JH, Cheng R, Schupf N, Manly J, Lantigua R, Stern Y, et al. The association between genetic variants in SORL1 and Alzheimer disease in an urban, multiethnic, community-based cohort. Arch Neurol. (2007) 64:501-6. doi: 10.1001/archneur.64.4.501

72. Lee JH, Cheng R, Rogaeva E, Meng Y, Stern Y, Santana V, et al. Further examination of the candidate genes in chromosome 12p13 locus for late-onset Alzheimer disease. Neurogenetics. (2008) 9:2. doi: 10.1007/s10048-008-0122-8

73. Lee JH, Barral S, Cheng R, Chacon I, Santana V, Williamson J, et al. Age-at-onset linkage analysis in Caribbean Hispanics with familial late-onset Alzheimer's disease. Neurogenetics. (2008) 9:127-38. doi: 10.1007/s10048-007-0103-3

74. Lee JH, Cheng R, Barral S, Reitz C, Medrano M, Lantigua R, et al. Identification of novel loci for Alzheimer disease and replication of CLU, PICALM, and BIN1 in Caribbean Hispanic individuals. Arch Neurol. (2011) 68:320-8. doi: 10.1001/archneurol.2010.292

75. Lee JH, Cheng R, Vardarajan B, Lantigua R, Dumeyeer DR, Ortmann W, et al. Genetic Modifiers of Age at Onset in Carriers of the G206A Mutation in PSEN1 With Familial Alzheimer Disease Among Caribbean Hispanics. JAMA Neurol. (2015) 72:1043-51. doi: 10.1001/jamaneurol.2015.1424

76. Livney MG, Clark CM, Karlawish JH, Cartmell S, Negron M, Nunez $\mathrm{J}$, et al. Ethnoracial differences in the clinical characteristics of Alzheimer's disease at initial presentation at an urban Alzheimer's disease center. Am J Geriatr Psychiatry. (2011) 19:430-9. doi: 10.1097/JGP. 0b013e3181f7d 881
77. Logue MW, Schu M, Vardarajan BN, Buros J, Green RC, Go RCP, et al. A comprehensive genetic association study of Alzheimer disease in African Americans. Arch Neurol. (2011) 68:1569-79. doi: 10.1001/archneurol.2011.646

78. Logue MW, Schu M, Vardarajan BN, Farell J, Bennett DA, Buxbaum JD, et al. Two rare AKAP9 variants are associated with Alzheimer's disease in African Americans. Alzheimers Dement. (2014) 10:609-18. doi: 10.1016/j.jalz.2014.06.010

79. Logue MW, Lancour D, Farrell J, Simhina I, Fallin MD, Lunetta KL, et al. Targeted Sequencing of Alzheimer Disease Genes in African Americans Implicates Novel Risk Variants. Front Neurosci. (2018) 12:592. doi: 10.3389/fnins.2018.00592

80. Marden JR, Walter S, Tchetgen Tchetgen EJ, Kawachi I, Glymour MM. Validation of a polygenic risk score for dementia in black and white individuals. Brain Behav. (2014) 4:687-97. doi: 10.1002/brb3.248

81. Marden JR, Mayeda ER, Walter S, Vivot A, Tchetgan EJT, Kawachi I, et al. Using an Alzheimer Disease Polygenic Risk Score to Predict Memory Decline in Black and White Americans Over 14 Years of Follow-up. Alzheimer Dis Assoc Disord. (2016) 30:195-202. doi: 10.1097/WAD.0000000000000137

82. McAninch E, Rajan K, Evans D, Jo S, Chaker L, Peeters R, et al. A common DIO2 polymorphism and Alzheimer disease dementia in African and European Americans. J Clin Endocrinol Metab. (2018) 103:505-30. doi: 10.1210/jc.2017-01196

83. Melville S, Buros J, Parrado A, Vardarajan B, Logue M, Shen L, et al. Multiple loci influencinghippocampal degeneration identified by genome scan. Ann Neurol. (2012) 72:108-20. doi: 10.1002/ana.23644

84. Mez J, Chung J, Jun G, Kriegel J, Bourias A, Sherva R, Logue $\mathrm{M}$, et al. Two novel loci, COBL andSLC10A2, for Alzheimer's disease in African Americans. Alzheimer's Dement. (2017) 13:45-81. doi: 10.1016/j.jalz.2016.09.002

85. Mount D, Ashley A, Lah J, Levey A, Goldstein F. Is ApoE $\varepsilon 4$ Associated with Cognitive Functioning in African Americans Diagnosed with Alzheimer Disease? An Exploratory Study. South Med J. (2009) 102:945-8. doi: 10.1097/SMJ.0b013e3181b21b82

86. Murrell JR, Price B, Lane KA, Baiyewu O, Gureje O, Ogunnieyi A, et al. Association of apolipoprotein E genotype and Alzheimer disease in African Americans. Arch Neurol. (2006) 63:431-4. doi: 10.1001/archneur.63.3.431

87. N'Songo A, Carrasquillo MM, Wang X, Burgess JD, Nguyen T, Asmann YW, et al. African American exome sequencing identifies potential risk variants at Alzheimer disease loci. Neurol Genet. (2017) 3:e141. doi: 10.1212/NXG.0000000000000141

88. O’Bryant SE, Johnson L, Balldin V, Edwards M, Barbar R, Williams $\mathrm{B}$, et al. Characterization of Mexican Americans with mild cognitive impairment and Alzheimer's disease. J Alzheimers Dis. (2013) 33:373-9. doi: 10.3233/JAD-2012-121420

89. O’Bryant SE, Johnson L, Reisch J, Edwards M, Hall J, Barbar R, et al. Risk factors for mild cognitive impairment among Mexican Americans. Alzheimers Dement. (2013) 9:622-31. doi: 10.1016/j.jalz.2012.12.007

90. Olarte L, Schupf N, Lee JH, Tang MX, Santana V, Williamson J, et al. Apolipoprotein E epsilon4 and age at onset of sporadic and familial Alzheimer disease in Caribbean Hispanics. Arch Neurol. (2006) 63:1586-90. doi: 10.1001/archneur.63.11.1586

91. Pedraza O, Allen M, Jennette K, Carrasquilo M, Crook J, Serie D, et al. Evaluation of memory endophenotypes for association with CLU, CR1, and PICALM variants in black and white subjects. Alzheimers Dement. (2014) 10:205-13. doi: 10.1016/j.jalz.2013.01.016

92. Peila R, Yucesoy B, White LR, Johnson V, Kashon ML, Wu K, et al. A TGF-betal polymorphism association with dementia and neuropathologies: the HAAS. Neurobiol Aging. (2007) 28:1367-73. doi: 10.1016/j.neurobiolaging.2006.06.004

93. Petrovitch H, Ross GW, He Q, Lock JU, Markesbery W, Davis D, et al. Characterization of Japanese-American men with a single neocortical AD lesion type. Neurobiol Aging. (2008) 29:1448-55. doi: 10.1016/j.neurobiolaging.2007.03.026

94. Qian J, Wolters FJ, Beiser A, Haan M, Ikram MA, Karlawish J, et al. APOE-related risk of mild cognitive impairment and dementia for prevention trials: An analysis of four cohorts. PLoS Med. (2017) 14:e1002254. doi: 10.1371/journal.pmed.1002254 
95. Rajabli F, Feliciano BE, Celis K, Nelson KLH, Whitehead PL, Adams $\mathrm{LD}$, et al. Ancestral origin of ApoE $\varepsilon 4$ Alzheimer disease risk in Puerto Rican and African American populations. PLoS Genet. (2018) 14:e1007791. doi: 10.1371/journal.pgen.1007791

96. Reitz C, Tokuhiro S, Clark LN, Conrad C, Vonsattel JP, Hazrati LN, et al. SORCS1 alters amyloid precursor protein processing and variants may increase Alzheimer's disease risk. Ann Neurol. (2011) 69:47-64. doi: 10.1002/ana.22308

97. Reitz C, Cheng R, Schupf N, Lee JH, Mehta PD, Rogaeva E, et al. Association between variants in IDE-KIF11-HHEX and plasma amyloid $\beta$ levels. Neurobiol Aging. (2012) 199:e13-7. doi: 10.1016/j.neurobiolaging.2010.07.005

98. Moher D, Liberati A, Tetzlaff J, Altman DG, for the PRISMA Group. Preferred reporting items for systematic reviews and meta-analyses: the PRISMA statement. BMJ. (2009) 339:b2535. doi: 10.1136/bmj.b2535

99. Rippon GA, Tang MX, Lee JH, Lantigua R, Medrano M, Mayeux R. Familial Alzheimer disease in Latinos: interaction between APOE, stroke, and estrogen replacement. Neurology. (2006) 66:35-40. doi: 10.1212/01.wnl.0000191300.38571.3e

100. Roses AD, Lutz MW, Saunders AM, Goldgaber D, Saul R, et al. African-American TOMM40'523-APOE haplotypes are admixture of West African and Caucasian alleles. Alzheimers Dement. (2014) 10:592-601. doi: 10.1016/j.jalz.2014.06.009

101. Saczynski JS, White L, Peila RL, Rodriguez BL, Launer LJ. The relation between apolipoprotein A-I and dementia: the Honolulu-Asia aging study. Am J Epidemiol. (2007) 165:91-9. doi: 10.1093/aje/kwm027

102. Sawyer K, Sachs-Ericsson N, Preacher KJ, Blazer DG. Racial differences in the influence of the APOE epsilon 4 allele on cognitive decline in a sample of community-dwelling older adults. Gerontology. (2009) 55:105-20. doi: $10.1159 / 000137666$

103. Simino J, Wang Z, Bressler J, Chouraki V, Yang Q, Younkin SG,et al. Whole exome sequence-based association analyses of plasma amyloid$\beta$ in African and European Americans; the Atherosclerosis Risk in Communities-Neurocognitive Study. PLoS One. (2017) 12:e0180046. doi: 10.1371/journal.pone.0180046

104. Tosto G, Bird TD, Tsuang D, Bennett DA, Boeve BF, Crushaga C, et al. Polygenic risk scores in familial Alzheimer disease. Neurology. (2017) 88:1180-86. doi: 10.1212/WNL.0000000000003734

105. Vardarajan BN, Bruesegem SY, Harbour ME, et al. Identification of Alzheimer disease-associated variants in genes that regulate retromer function. Neurobiol Aging. (2012) 33:e15-e30. doi: 10.1016/j.neurobiolaging.2012.04.020

106. Vardarajan BN, Zhang Y, Lee JH, Cheng R, Bohm C, Ghani M, et al. Coding mutations in SORL1 and Alzheimer disease. Ann Neurol. (2015) 77:215-27. doi: 10.1002/ana.24305

107. Weiner MF, Hynan LS, Rossetti H, Womack KB, Rosenberg RN, Gong $\mathrm{YH}$, et al. The relationship of cardiovascular risk factors to Alzheimer disease in Choctaw Indians. Am J Geriatr Psychiatry. (2011) 19:423-9. doi: 10.1097/JGP.0b013e3181e89a46

108. Yu L, Lutz MW, Wilson RS, Burns DK, Roses AD, Saunders AM, et al. APOE 84 -TOMM40 '523 haplotypes and the risk of Alzheimer's disease in older Caucasian and African Americans. PLoS One. (2017) 12:e7-e9. doi: 10.1371/journal.pone.0180356

109. Reitz C, Jun G, Naj A, Rajbhandary R, Vardarajan BN, Wang L-S, et al. Variants in the ATP-binding cassette transporter (ABCA7), apolipoprotein E $\epsilon 4$, and the risk of late-onset Alzheimer disease in African Americans. JAMA. (2013) 309:1483-92. doi: 10.1001/jama.2013.2973

110. Barnes LL, Leurgans S, Aggarwal NT, Shah RC, Arvanitakis Z, James BD, et al. Mixed pathology is more likely in black than white decedents with Alzheimer dementia. Neurology. (2015) 85:528-34. doi: 10.1212/WNL.0000000000001834

111. Kunkle BW, Schmidt $M$, Klein H-U, Naj AC, Hamilton-Nelson KL, Larson EB, et al. Novel Alzheimer disease risk loci and pathways in African American individuals using the african genome resources panel: a meta-analysis. JAMA Neurol. (2021) 78:102-13. doi: 10.1001/jamaneurol.2020.3536

112. Nussbaum RL. Genome-wide association studies, Alzheimer disease, and understudied populations. JAMA. (2013) 309:15278. doi: 10.1001/jama.2013.3507

113. Wojcik GL, Graff M, Nishimura KK, Tao R, Haessler J, Gignoux $\mathrm{CR}$, et al. Genetic analyses of diverse populations improves discovery for complex traits. Nature. (2019) 570:514-8. doi: 10.1038/s41586-019 $-1310-4$

114. McGinnis JM, Williams-Russo P, Knickman JR. The case for more active policy attention to health promotion. Health Aff (Millwood). (2002) 21:7893. doi: 10.1377/hlthaff.21.2.78

115. Adler NE, Newman K. Socioeconomic disparities in health: pathways and policies. Health Aff (Millwood). (2002) 21:60-76. doi: 10.1377/hlthaff. 21.2.60

116. Mahoney DF, Cloutterbuck J, Neary S, Zhan L. African American, Chinese, and Latino family caregivers' impressions of the onset and diagnosis of dementia: cross-cultural similarities and differences. Gerontologist. (2005) 45:783-92. doi: 10.1093/geront/45.6.783

117. Jang Y, Kim G, Chiriboga D. Knowledge of Alzheimer's disease, feelings of shame, and awareness of services among Korean American elders. J Aging Health. (2010) 22:419-33. doi: 10.1177/ 0898264309360672

118. Liu D, Hinton L, Tran C, Hinton D, Barker JC. Reexamining the relationships among dementia, stigma, and aging in immigrant Chinese and Vietnamese family caregivers. J Cross Cult Gerontol. (2008) 23:28399. doi: $10.1007 / \mathrm{s} 10823-008-9075-5$

Conflict of Interest: The authors declare that the research was conducted in the absence of any commercial or financial relationships that could be construed as a potential conflict of interest.

Publisher's Note: All claims expressed in this article are solely those of the authors and do not necessarily represent those of their affiliated organizations, or those of the publisher, the editors and the reviewers. Any product that may be evaluated in this article, or claim that may be made by its manufacturer, is not guaranteed or endorsed by the publisher.

Copyright (C) 2021 Rubin, Ingram, Resciniti, Ashford-Carroll, Leith, Rose, Ureña, McCollum and Friedman. This is an open-access article distributed under the terms of the Creative Commons Attribution License (CC BY). The use, distribution or reproduction in other forums is permitted, provided the original author(s) and the copyright owner(s) are credited and that the original publication in this journal is cited, in accordance with accepted academic practice. No use, distribution or reproduction is permitted which does not comply with these terms. 